Iyem, E., Yildirim, M., Kizilgeci, F. (2021): Germination, seedling growth and physio-biochemical indices of bread wheat (Triticum aestivum L.) genotypes under peg induced drought stress. Agriculture and Forestry, 67(1): $163-180$

DOI: 10.17707/AgricultForest.67.1.14

Ece IYEM ${ }^{1}$, Mehmet YILDIRIM ${ }^{1}$, Ferhat KIZILGECI ${ }^{2}$

\title{
GERMINATION, SEEDLING GROWTH AND PHYSIO-BIOCHEMICAL INDICES OF BREAD WHEAT (Triticum aestivum L.) GENOTYPES UNDER PEG INDUCED DROUGHT STRESS
}

\begin{abstract}
SUMMARY
The establishment of seedlings at early growth stages of plants is one of the important determinants for higher yield potential under stress conditions. Therefore, high germination rate and vigorous seedling growth under water stress conditions is preferred to increase productivity. Considering this issue, an experiment was conducted to know the response of drought stress on the germination and seedling growth traits of available wheat cultivars. The study was carried out at the Laboratory of Horticulture in Agriculture Faculty, Cukurova University, Turkey. Seeds of five bread wheat genotypes viz. Wafia, Lucilla, Envoy, DZ19-2 and DZ19-1 were placed and grown in Petri-dishes under polyethylene glycol (PEG 6000) induced drought stresses of 0 (control=distilled water), $-0.2,-0.4$ and $-0.6 \mathrm{MPa}$ conditions for evaluation the properties of germination and seedling growth. Regarding the root length and dry weight, the genotypes Wafia, Lucilla and DZ19-1were found superior and seemed to be relatively tolerant to drought stress over other genotypes. Regarding biochemical analysis, the proline content increased with increasing drought levels, where the maximum proline was observed in the DZ19-1 genotype. Due to drought stress, the shoot proline content increased in drought-tolerant wheat genotypes whereas the proline level decreased in the sensitive ones compared to the control. Considering the study, the genotype DZ19-1 can be treated as drought tolerant genotype, and further investigations are needed, however, to support our understanding of the drought stress effects during the whole life cycle of wheat.
\end{abstract} proline

Keywords: Water stress, growth indices, biochemicals, wheat genotypes,

\section{INTRODUCTION}

Crop production is usually restricted by abiotic stress factors such as drought, temperature, and salinity. During crop production, seed germination and seedling establishment are the most sensitive stages to abiotic stresses particularly

\footnotetext{
${ }^{1}$ Ece Iyem, Mehmet Yildirim, Department of Field Crops, Faculty of Agriculture, Dicle University, Diyarbakir, TURKEY

${ }^{2}$ Ferhat Kizilgeci (corresponding author: ferhatkizilgeci@artuklu.edu.tr) Department of Seed Production, Kiziltepe Vocational School, Mardin Artuklu University, Mardin, TURKEY

Notes: The authors declare that they have no conflicts of interest. Authorship Form signed online. 
to water deficit stress (Patade et al., 2011; Kizilgeci et al., 2020). The incidence of drought is increasing day by day owing to global warming which ultimately affecting the agriculture. Drought stress at germination stage reduced the seedling emergence and establishment (El Sabagh et al., 2019; Salih and Tuncturk, 2020). Drought stress delays seed germination declines germination rate, and also significantly changes the physiology and biochemistry in seedling (Bateman et al., 2016). Extreme water shortage causes a considerable reduction of morphophysiological and metabolic activities in plants, and ultimately reduces yield and quality of crop (Aslam et al., 2013). In some cases, plants exhibit adaptation to withstand water stress (Mickky and Aldesuquy, 2017). Under drought stress, the morphology, physiology, biochemistry in a plant would be adversely changed (Duan et al., 2017). Germination, a very sensitive stage in plants life cycle (as it determines the degree of crop establishment), is severely affected by salinity (Vardar et al., 2014).

Wheat is a major cereal crop in many parts of the world, and it is commonly known as king of cereals. Wheat grain yield is depressed by environmental stresses such as drought, heat, low temperatures, low fertility (especially nitrogen) and soil salinity (Barutcular et al., 2017; Dončić et al., 2019; Panfilova, and Mohylnytska, 2019; Guo et al., 2020; Zaman et al., 2020). Therefore, a great attention has been made to produce wheat under various environmental stresses (Mickky and Aldesuquy, 2017; Mubeen et al., 2020 Popović et al., 2020). Drought is a deleterious factor among environmental stresses that can reduce wheat yield (Abbasi et al., 2015; Barutçular et al., 2017). There are many factors which are greatly influenced the growth and productivity of crops by alleviating the drought stress effects, and selection of and cultivation drought tolerant cultivars is the most important one. Therefore, existing wheat varieties should be evaluated under drought stress conditions at seed germination and early seedling growth stages, and promising drought tolerant varieties should be recommended for crop cultivation (Alom et al., 2016). Hence, screening of wheat genotypes should be made under naturally or artificially induced drought stress, and polyethylene glycol (PEG 6000) is used to induce artificial drought stress. PEG is a flexible, water-soluble polymer, and creates very high osmotic pressures. These properties make PEG one of the most useful molecules for applying osmotic pressure in biochemistry and bio-membranes experiments, in particular when using the osmotic stress technique (Partheeban et al., 2017; Wikipedia, 2020). The present study was, therefore, undertaken to evaluate and select tolerant wheat genotypes for verifying their responses under different levels of PEG induced drought stress during the seed germination and seedling growth stages.

\section{MATERIAL AND METHODS}

The study was carried out at the Horticulture Laboratory, Faculty of Agriculture, Cukurova University, Turkey. The form of experiment was factorial which was laid out in a completely randomized design (CRD) with thrice in replication. Five bread wheat genotypes (Wafia, Lucilla, Envoy, DZ19-1 and 
DZ19-2) were placed to petri dishes under four levels of PEG induced drought stresses viz. control (distilled water), -0.2, -0.4 and -0.6 MPa under laboratory conditions to study the properties of germination and early seedling growth.

Seeds of different wheat genotypes were treated with a $5 \%$ solution of sodium hypochlorite for $10 \mathrm{~min}$, and residual chlorine effect was removed by washing the seeds thoroughly with distilled water. The 20 seeds were placed on two layers of Whatman no. 2 filter paper with $12 \mathrm{~cm}$ diameter Petri-dishes. Day and night lengths were $18 / 6 \mathrm{~h}$, with $24 \pm 1^{\circ} \mathrm{C}$. Drought conditions were created by using PEG-6000 according to the treatment specification.

The seedlings were grown up to 7 days and then harvested. The germination and seedling growth traits like seed vigor, shoot and root lengths, coleoptile length, fresh weight of shoot and root fresh weight were measured. Turgor weight, shoot and root dry weight were measured for each plant after drying the samples in an oven at $72^{\circ} \mathrm{C}$ temperature for $48 \mathrm{~h}$, and the relative water content (RWC) was calculated by using the following formulae:

$\mathrm{RWC}=(\mathrm{FW}-\mathrm{DW}) \times 100 /(\mathrm{TW}-\mathrm{DW})$

Where, FW: Fresh weight, DW: Dry weight and TW: Turgid weight.

The proline content was measured following the protocol of Bates et al. (1973). The optical density of the extracted sample was recorded at $528 \mathrm{~nm}$ wavelength in spectrophotometer, and the proline was calculated using a calibration curve of L-proline concentration $(0-5 \mu \mathrm{g} / \mathrm{ml})$.

The chlorophyll (a, b, and total), and carotenoid contents were measured following the method developed by Agarwal (1986) with a slight modification by Higazy et al. (1995). The absorbance reading was taken from spectrophotometer at 480, 649 and $665 \mathrm{~nm}$ wavelengths.

The data were analyzed by partitioning the total variance with the help of a computer using MSTAT-C program (Gomez and Gomez, 1984). Duncan's Multiple Range Test was used to compare the treatment means (Duncan, 1955).

\section{RESULTS AND DISCUSSION}

The results of the germination and various growth characteristics of wheat seedlings under different drought stresses are shown in Table 1. Data revealed that drought stress adversely affected the seed vigor, root, coleoptile and seedling lengths, fresh and dry weights of root and shoot, RWC, proline, chlorophyll, and carotenoid content. The result of the present findings corroborates with the results of Partheeban et al. (2017), Kizilgeci et al. (2017), Guo et al. (2020), where they also noted that water deficit stress suppressed the membrane integrity by stimulating the lipid peroxidation as significant increase of membrane leakage.

Germination under drought condition is very important because it reflects the seedling establishment and crop yield (Mwale et al., 2003). Drought is a serious threat in agriculture among the abiotic stresses that limits the seed germination, seeding growth, plants growth and yield (Aslam et al., 2013; El Sabagh et al., 2019). The response of drought stress on the wheat cultivars varied 
regarding the germination rate, and germination index, used as drought tolerance indices at germination stage (Öztürk et al., 2016).

Table 1. Analysis of variance for seedling growth properties for genotypes and PEG concentrations

\begin{tabular}{|c|c|c|c|c|c|c|c|c|c|c|c|c|c|c|c|}
\hline SOV & $d f$ & RL & CL & SL & RFW & SFW & RDW & SDW & RWC & SV & Proline & Chl-a & Chl- $b$ & Cd & $\begin{array}{c}\text { Total } \\
\text { Chl }\end{array}$ \\
\hline Genotypes & 4 & $* *$ & $* *$ & $* *$ & $*$ & $* *$ & $* *$ & $* *$ & $\mathrm{~ns}$ & $* *$ & $* *$ & $* *$ & $* *$ & $* *$ & $* *$ \\
\hline Stresses & 3 & $* *$ & $* *$ & $* *$ & $* *$ & $* *$ & $* *$ & $* *$ & $* *$ & $* *$ & $* *$ & $* *$ & $* *$ & $* *$ & $* *$ \\
\hline $\mathrm{G} \times \mathrm{S}$ & 12 & $\mathrm{~ns}$ & $\mathrm{~ns}$ & $\mathrm{~ns}$ & $* *$ & $*$ & $\mathrm{~ns}$ & $* *$ & $* *$ & $\mathrm{~ns}$ & $* *$ & $* *$ & $* *$ & $* *$ & $* *$ \\
\hline $\mathrm{CV}(\%)$ & & 13.71 & 8.02 & 14.25 & 25 & 13.2 & 18.18 & 9.09 & 18.75 & 10.57 & 24.4 & 9.61 & 17.39 & 12.18 & 9.26 \\
\hline
\end{tabular}

$*=5 \%$ level of significance; $* *=1 \%$ level of significance; ns: not significant SOV: Source of variance, RL: Root length, CL: Coleoptile length, SL: Seedling length RFW: Root fresh weight SFW: Seedling fresh weight RDW: Root dry weight SDW: Seedling dry weight RWC: Relative water content SV: seedling vigour Chl-a : chlorophyll-a Chl-b: chlorophyll-b Cd: Carotenoid

\section{Root length}

Under drought stress condition, behaviour of roots is an important trait that triggers to other growth traits, and plants under drought stress enhance deeper roots to absorb available water in the soil which enables higher drought tolerance (Španić et al., 2017). The ANOVA of root length of bread wheat genotypes during the germination period under different levels of PEG-6000 induced stresses is presented in Table 1, whereas its mean values are given in Table 2 . The differences between genotypes and concentrations were found significant at $1 \%$ level. Statistically insignificant interaction between genotypes $\times$ levels of PEG6000 induced stress was observed. In the present study, the root length decreased significantly with increasing drought stress among the genotypes (Table 2). However, the shortest root length $(8.45 \mathrm{~cm})$ was recorded at DZ19-2 genotype as compared to other genotypes as they showed statistically similar root length. The genotype DZ19-1 showed the longest root lengths numerically $(10.65 \mathrm{~cm})$. The longer root length provides an advantage of plant roots to go deep in soil for uptake of water and nutrients. In general, it can be argued that DZ19-1, Wafia and Lucilla genotypes tolerated drought at all levels of drought stress. Nature of root length under drought stress is considered as an important index to select drought tolerant genotypes (Turner, 1997), considering the root morphology and growth rate (Malik et al., 2002). Remarkable decrease in root length with increasing PEG concentrations has been observed by Jajarmi et al. (2009). Under drought stress, plant could show the relative adaptability in terms of morphological, physiological, and biochemical changes in order to ensure the relatively stable growth of plant, for example, reduced leaf area and increased root activity (Mwadzingeni et al., 2016; Duan et al., 2017). Root is the main organ of plant to absorb water and nutrient, which reacts against drought stress at first (Janiak et al., 2015; Duan et al., 2017). 
Table 2. Response of PEG 6000 induced drought stress on the root length $(\mathrm{cm})$ of wheat genotypes

\begin{tabular}{|c|c|c|c|c|c|c|}
\hline \multirow{8}{*}{$\begin{array}{l}\text { Root } \\
\text { length } \\
\text { (cm) }\end{array}$} & \multirow[b]{2}{*}{ Genotypes } & \multicolumn{5}{|c|}{ Levels of stress (MPa) } \\
\hline & & 0 (control) & -0.2 & -0.4 & -0.6 & Mean \\
\hline & DZ19-2 & 12.62 & 7.92 & 7.55 & 5.72 & $8.45 \mathrm{~b}$ \\
\hline & Lucilla & 12.86 & 12.02 & 9.03 & 6.24 & $10.04 \mathrm{a}$ \\
\hline & DZ19-1 & 14.29 & 11.49 & 9.81 & 7.03 & 10.65 \\
\hline & Envoy & 12.80 & 11.53 & 9.31 & 6.23 & 9.97 \\
\hline & Wafia & 14.83 & 11.61 & 8.30 & 5.70 & $10.11 \mathrm{a}$ \\
\hline & Mean & $13.48 \mathrm{a}$ & $10.91 \mathrm{~b}$ & $8.8 \mathrm{c}$ & $6.18 \mathrm{~d}$ & \\
\hline
\end{tabular}

Means within columns followed by different lowercase letters are significantly different

Table 3. Response of PEG 6000 induced drought stress on the coleoptile length $(\mathrm{cm})$ of wheat genotypes

\begin{tabular}{|l|l|l|l|l|l|l|}
\hline \multirow{4}{*}{$\begin{array}{l}\text { Coleoptile } \\
\text { length }\end{array}$} & Genotypes & \multicolumn{5}{|c|}{ Levels of stress (MPa) } \\
\cline { 2 - 7 }$(\mathbf{c m})$ & & $\mathbf{0}$ (control) & $\mathbf{- 0 . 2}$ & $\mathbf{- 0 . 4}$ & $\mathbf{- 0 . 6}$ & Mean \\
\cline { 2 - 7 } & DZ19-2 & 2.65 & 2.74 & 3.17 & 2.81 & $2.84 \mathrm{a}$ \\
\cline { 2 - 7 } & Lucilla & 2.41 & 2.55 & 2.75 & 2.43 & $2.54 \mathrm{c}$ \\
\cline { 2 - 7 } & En19-1 & 2.75 & 3.05 & 2.96 & 2.96 & $2.93 \mathrm{a}$ \\
\cline { 2 - 7 } & Wafia & 2.79 & 2.89 & 2.86 & 2.48 & $2.76 \mathrm{ab}$ \\
\cline { 2 - 7 } & Mean & $2.62 \mathrm{c}$ & 2.73 & 2.82 & 2.52 & $2.64 \mathrm{bc}$ \\
\hline
\end{tabular}

Means within columns followed by different lowercase letters are significantly different

Table 4. Response of PEG 6000 induced drought stress on the seedling length $(\mathrm{cm})$ of wheat genotypes

\begin{tabular}{|l|l|l|l|l|l|l|}
\hline \multirow{4}{*}{\begin{tabular}{l} 
Geedling \\
\multirow{4}{*}{$\begin{array}{l}\text { length } \\
\text { (cm) }\end{array}$}
\end{tabular}} & \multicolumn{5}{|c|}{ Levels of stress (MPa) } \\
\cline { 2 - 7 } & DZ19-2 & $\mathbf{0}$ (control) & $\mathbf{- 0 . 2}$ & $\mathbf{- 0 . 4}$ & $\mathbf{- 0 . 6}$ & Mean \\
\cline { 2 - 7 } & Lucilla & 14.15 & 10.13 & 10.85 & 7.11 & $10.06 \mathrm{~b}$ \\
\cline { 2 - 7 } & DZ19-1 & 15.81 & 12.19 & 10.69 & 7.43 & $11.26 \mathrm{ab}$ \\
\cline { 2 - 7 } & Envoy & 12.54 & 12.19 & 12.46 & 8.16 & $12.52 \mathrm{a}$ \\
\cline { 2 - 7 } & Wafia & 16.10 & 10.67 & 9.68 & 6.90 & $10.41 \mathrm{~b}$ \\
\cline { 2 - 7 } & Mean & $14.27 \mathrm{a}$ & $11.77 \mathrm{~b}$ & $10.74 \mathrm{~b}$ & $7.28 \mathrm{c}$ & \\
\hline
\end{tabular}

Means within columns followed by different lowercase letters are significantly different

\section{Coleoptile length}

The differences between genotypes and stress levels were determined at $1 \%$ level of significance but the interaction between genotypes $\times$ PEG-6000 stress was found statistically insignificant (Table 1). The coleoptile length of wheat cultivars was significantly influenced by the imposition of drought stress, and it decreased considerably with the increasing concentration of PEG6000 induced stresses (Table 3). However, the coleoptile lengths were seen to increase 
up to-0.4 MPa stress, and thereafter decreased at $-0.6 \mathrm{MPa}$ stress, but the values were higher over control condition. This shows that wheat genotypes tend to increase coleoptile lengths in response to drought stress. Wheat genotypes showed differential responses due to magnitude of drought stresses. The genotype DZ19-1 produced the highest coleoptile length which was statistically similar to Envoy and DZ19-2 under drought stress, while the lowest was recorded for Lucilla. Drought stress suppressed the seed germination which retarded the growth of young seedling, reduced the length of plumules and radicles, fresh weight of seedlings and relative water content of wheat genotypes (Mickky and Aldesuquy, 2017).

\section{Seedling length}

The variations among the genotypes as well as stress levels were found to be significant at $1 \%$ level, but the interaction between genotypes $\times$ PEG-6000 concentrations was found to be statistically insignificant (Table 1). Wafia genotype had the longest shoot lengths $(16.10 \mathrm{~cm})$ under control conditions followed by DZ19-1 $(15.81 \mathrm{~cm})$. As drought stress increased, there was a noticeable decline in seedling length. The shortest shoot length $(6.83 \mathrm{~cm})$ was observed in Wafia genotype under severe stress condition, which had the highest shoot length under control conditions demonstrating its sensitivity to drought conditions (Table 4). The genotype DZ19-1 had the longest shoot lengths of 8.16 and $12.52 \mathrm{~cm}$ under control condition and drought stress of $-0.6 \mathrm{MPa}$, respectively indicating that DZ19-1is resistant to drought stress. Similarly, in their research, Kizilgeci et al. (2017) reported that PEG induced stress of -1.2 MPa caused a drastic reduction of seedling length in comparison to $-0.3 \mathrm{MPa}$ stress. Drought stress severely reduced the seedling growth of wheat genotypes (Španić et al., 2017).

\section{Root fresh weight}

The root fresh weight of all wheat genotypes was markedly decreased with the increasing PEG induced stress over control. The mean root fresh weights of genotypes decreased with increasing the drought stress concentration (Table 5). The genotype Wafia had the highest root fresh weight under the control condition which was followed by DZ19-2 and Lucilla, while the highest root fresh weight $(50.0 \mathrm{mg})$ was observed in DZ19-1, and the lowest $(16.8 \mathrm{mg})$ was in Lucilla genotype at $-0.6 \mathrm{MPa}$ stress condition. DZ19-1 was observed to maintain the maximum root fresh weight compared to other genotypes under increased drought stress, although it maintained the minimum root fresh weight $(46 \mathrm{mg})$ at the control condition and can be treated as drought stress resistant genotype.

\section{Seedling fresh weight}

The Seedling fresh weight was significantly affected by the PEG induced drought stress, genotypes, and their interaction (Table 1). The differences among the genotypes and stress levels were highly significant (1\% level), and their interaction effect was also significant (5\% level). There was no statistical difference between control and $-0.2 \mathrm{MPa}$ induced stress on the seedling fresh 
weight, while the average seedling fresh weight decreased as the stress level increased. Nonetheless, DZ19-1 genotype obtained the highest seedling fresh weight $(42.9 \mathrm{mg})$ under severe drought stress, indicating its tolerance to drought stress (Table 6). These results were adhering to the results of Sayar et al. (2010) and Španić et al. (2017), who reported that the seedling fresh weight of wheat genotypes decreased with increasing the osmotic stress.

\section{Root dry weight}

The root dry weight was influenced significantly (1\% level) by different genotypes, and stress levels whereas no remarkable variation regarding the root dry weight was observed by the interaction effect of genotypes and stress levels (Table 1)

Table 5. Response of PEG 6000 induced drought stress on the root fresh weight (mg)of wheat genotypes

\begin{tabular}{|c|l|l|l|l|l|l|}
\hline \multirow{4}{*}{$\begin{array}{c}\text { Root } \\
\text { fresh } \\
\text { weight } \\
(\mathbf{m g})\end{array}$} & Genotypes & \multicolumn{5}{|c|}{ Levels of stress (MPa) } \\
\cline { 2 - 7 } & & $\mathbf{0}$ (control) & $\mathbf{- 0 . 2}$ & $\mathbf{- 0 . 4}$ & $\mathbf{- 0 . 6}$ & Mean \\
\cline { 2 - 7 } & Lucilla & $68.2 \mathrm{a}$ & $44.0 \mathrm{ef}$ & $50.7 \mathrm{cf}$ & $21.6 \mathrm{gh}$ & $46.1 \mathrm{bc}$ \\
\cline { 2 - 7 } & DZ19-1 & $46.0 \mathrm{def}$ & $36.1 \mathrm{fg}$ & $37.8 \mathrm{fg}$ & $50.0 \mathrm{c}-\mathrm{f}$ & $42.5 \mathrm{c}$ \\
\cline { 2 - 7 } & Envoy & $61.8 \mathrm{a}-\mathrm{d}$ & $47.7 \mathrm{c}-\mathrm{f}$ & $58.1 \mathrm{a}-\mathrm{e}$ & $43.0 \mathrm{ef}$ & $52.7 \mathrm{ab}$ \\
\cline { 2 - 7 } & Wafia & $73.8 \mathrm{a}$ & $64.2 \mathrm{abc}$ & $48.9 \mathrm{c}-\mathrm{f}$ & $38.0 \mathrm{fg}$ & $56.2 \mathrm{a}$ \\
\cline { 2 - 7 } & Mean & $63.7 \mathrm{a}$ & $49.0 \mathrm{~b}$ & $48.2 \mathrm{~b}$ & $33.9 \mathrm{c}$ & \\
\hline
\end{tabular}

Means within columns followed by different lowercase letters are significantly different

Table 6. Response of PEG 6000 induced drought stress on the seedling fresh weight (mg) of wheat genotypes

\begin{tabular}{|c|l|l|l|l|l|l|}
\hline \multirow{4}{*}{$\begin{array}{c}\text { Seedling } \\
\text { fresh } \\
\text { weight(mg) }\end{array}$} & Genotypes & \multicolumn{5}{|c|}{ Levels of stress (MPa) } \\
\cline { 2 - 7 } & & $\mathbf{0}$ (control) & $\mathbf{- 0 . 2}$ & $\mathbf{- 0 . 4}$ & $\mathbf{- 0 . 6}$ & Mean \\
\cline { 2 - 7 } & DZ19-2 & $67.2 \mathrm{a}$ & $67.8 \mathrm{ab}$ & $59.4 \mathrm{bcd}$ & $33.7 \mathrm{~h}$ & $57.0 \mathrm{a}$ \\
\cline { 2 - 7 } & DZ19-1 & $41.4 \mathrm{fgh}$ & $54.2 \mathrm{cde}$ & $49.6 \mathrm{~d}-\mathrm{g}$ & $35.6 \mathrm{~h}$ & $45.2 \mathrm{~b}$ \\
\cline { 2 - 7 } & Envoy & $72.1 \mathrm{a}$ & $63.5 \mathrm{abc}$ & $56.1 \mathrm{bcd}$ & $42.9 \mathrm{e}-\mathrm{h}$ & $58.7 \mathrm{a}$ \\
\cline { 2 - 7 } & Wafia & $64.4 \mathrm{a}$ & $56.8 \mathrm{bcd}$ & $52.9 \mathrm{c}-\mathrm{f}$ & $37.4 \mathrm{gh}$ & $55.4 \mathrm{a}$ \\
\cline { 2 - 7 } & Mean & $63.9 \mathrm{a}$ & $62.7 \mathrm{abc}$ & $49.5 \mathrm{~d}-\mathrm{g}$ & $37.7 \mathrm{gh}$ & $53.6 \mathrm{a}$ \\
\hline
\end{tabular}

Means within columns followed by different lowercase letters are significantly different

The root dry weight decreased with the increasing drought stress levels. The genotype Envoy maintained the highest and lowest root dry weight (15.7 and $11.1 \mathrm{mg}$ ) both at control and -0.6 MPa PEG conditions, respectively (Table 7). The minimum root dry weight was recorded in Wafia genotype at severe water stress $(-0.6 \mathrm{MPa})$ which reduced root dry weight by $42.85 \%$ over control, whereas the reduction was only by $31.25 \%$ in Envoy genotype at same condition. In root development, Envoy, DZ19-1 and Wafia genotypes showed better results in stress 
conditions compared to other genotypes when examined in length and age. The decreasing trends of the shoot and root dry weight with increasing drought stress was reported previously by Chachar et al. (2014) and Molla et al., (2019). Our results are line with the results of Jatoi et al. (2014), who concluded that the root dry weight of wheat genotypes was reduced gradually with the increasing PEG concentrations.

\section{Seedling dry weight}

Seedling dry weight is the consequence of plant physiological and biological activities. Seedling dry weight values were decreased with the increase of PEG6000 concentrations in all wheat genotypes. Differences among the genotypes, stress levels, and their interaction were found to be significant at $1 \%$ level. According to the results, the shoot dry weight ranged from $8.2 \mathrm{mg}$ to 16.8 $\mathrm{mg}$ owing to the interaction between stress levels and genotypes (Table 8). When the differences among water stress levels were analysed, the seedling dry weight decreased statistically with the imposing of moderate and severe $(-0.6 \mathrm{MPa})$ drought stresses. The Wafia genotype, which had the highest seedling dry weight under control conditions, was found to reduce drastically (52.94\%) at $-0.6 \mathrm{MPa}$ compare to other genotypes. Islam et al. (2018) depicted that the seedlings dry weight decreased with the increasingPEG6000 induced stress levels in rice genotypes. Rana et al. (2017) found a wide difference among wheat genotypes to stress tolerance based on their tolerance index for seedling dry weight.

\section{Relative water content}

Relative water content (RWC) was used as a measure of drought tolerance indicator. PEG-induced drought stress considerably reduced the RWC in the shoot over control (Table 9). The differences among the stress levels were significant regarding the RWC at the level of 5\%, and the interaction between PEG-6000 induced stress and genotypes was found significant at the level of $1 \%$. However, the differences among the genotypes were found statistically insignificant. From the study, it is shown that the RWC decreased with the increment of drought stresses. Among all, the genotype Lucilla showed the highest RWC at severe stress conditions. Many researchers (Yassin et al., 2019; Monsur et al., 2020) confirmed that proline is accumulated in crops under stress environment. Drought stress induced by PEG decreased the water status in shoot which is consistent with the study of Guoxiong et al. (2002), who reported that PEG induced drought stress significantly decreased the RWC. It is reported earlier that larger seeds produced longer root lengths that help to uptake more water resulting in higher RWC in shoot (Kaydan and Yagmur, 2008) 


\section{Seed vigour}

Vigour test does not only measure the percentage of viable seeds in a sample, it also reflects the ability of those seeds to produce normal seedlings under adverse growing conditions alike to field conditions. The differences among the genotypes and water deficit stresses regarding the seed vigour were found significant at $1 \%$ level, but their interactions were found statistically insignificant (Table 1).

Table 7. Effect of PEG 6000 induced drought stress on the root dry weight (mg) of wheat genotypes

\begin{tabular}{|c|l|l|l|l|l|l|}
\hline \multirow{4}{*}{$\begin{array}{c}\text { Root dry } \\
\text { Genotypes }\end{array}$} & \multicolumn{5}{|c|}{ Levels of stress (MPa) } \\
\cline { 2 - 7 } $\begin{array}{c}\text { weight } \\
(\mathbf{m g})\end{array}$ & & $\mathbf{0}$ (control) & $\mathbf{- 0 . 2}$ & $\mathbf{- 0 . 4}$ & $\mathbf{- 0 . 6}$ & Mean \\
\cline { 2 - 7 } & Lucilla & $11.3 \mathrm{cde}$ & $8.3 \mathrm{e}$ & $8.2 \mathrm{e}$ & $7.6 \mathrm{e}$ & $8.8 \mathrm{~d}$ \\
\cline { 2 - 7 } & DZ19-1 & $13.2 \mathrm{ab}$ & $16.7 \mathrm{a}$ & $15.6 \mathrm{ab}$ & $9.1 \mathrm{de}$ & $14.1 \mathrm{a}$ \\
\cline { 2 - 7 } & Envoy & $15.7 \mathrm{ab}$ & $10.9 \mathrm{cde}$ & $12.4 \mathrm{bcd}$ & $10.2 \mathrm{cde}$ & $11.7 \mathrm{bc}$ \\
\cline { 2 - 7 } & Wafia & $14.0 \mathrm{abc}$ & $13.0 \mathrm{abc}$ & $10.3 \mathrm{cde}$ & $8.1 \mathrm{e}$ & $11.3 \mathrm{c}$ \\
\cline { 2 - 7 } & Mean & $13.9 \mathrm{a}$ & $12.5 \mathrm{ab}$ & $11.9 \mathrm{~b}$ & $9.2 \mathrm{c}$ & \\
\hline
\end{tabular}

Means within columns followed by different lowercase letters are significantly different

Table 8. Response of PEG 6000 induced drought stress on the seedling dry weight $(\mathrm{mg})$ of wheat genotypes

\begin{tabular}{|l|l|l|l|l|l|l|}
\hline \multirow{4}{*}{$\begin{array}{l}\text { Seedling } \\
\text { dry } \\
\text { weight } \\
(\mathbf{m g})\end{array}$} & \multirow{4}{*}{\begin{tabular}{l} 
Genotypes \\
\cline { 2 - 7 }
\end{tabular}} & $\mathbf{0}($ control) & $\mathbf{- 0 . 2}$ & $\mathbf{- 0 . 4}$ & $\mathbf{- 0 . 6}$ & Mean \\
\cline { 2 - 7 } & LZ19-2 & $14.8 \mathrm{abc}$ & $16.4 \mathrm{ab}$ & $12.3 \mathrm{c}-\mathrm{f}$ & $7.8 \mathrm{j}$ & $12.8 \mathrm{a}$ \\
\cline { 2 - 7 } & DZ19-1 & $12.1 \mathrm{~d}-\mathrm{g}$ & $11.1 \mathrm{e}-\mathrm{h}$ & $9.6 \mathrm{~g}-\mathrm{j}$ & $8.2 \mathrm{ij}$ & $10.2 \mathrm{c}$ \\
\cline { 2 - 7 } & Envoy & $13.9 \mathrm{cde}$ & $11.3 \mathrm{~d}-\mathrm{h}$ & $12.3 \mathrm{c}-\mathrm{f}$ & $8.2 \mathrm{ij}$ & $11.1 \mathrm{bc}$ \\
\cline { 2 - 7 } & Wafia & $16.8 \mathrm{a}$ & $10.6 \mathrm{e}-\mathrm{j}$ & $9.4 \mathrm{hij}$ & $8.9 \mathrm{hij}$ & $10.5 \mathrm{bc}$ \\
\cline { 2 - 7 } & Mean & $14.1 \mathrm{a}$ & $11.9 \mathrm{~b}$ & $10.9 \mathrm{~b}$ & $8.3 \mathrm{c}$ & $11.7 \mathrm{ab}$ \\
\hline
\end{tabular}

Means within columns followed by different lowercase letters are significantly different

Table 9. Effect of PEG 6000 induced drought stress on the relative water content of wheat genotypes

\begin{tabular}{|c|l|l|l|l|l|l|}
\hline \multirow{4}{*}{$\begin{array}{c}\text { Relative } \\
\text { water } \\
\text { content }\end{array}$} & Genotypes & \multicolumn{5}{|c|}{ Levels of stress (MPa) } \\
\cline { 2 - 7 } & & $\mathbf{0}($ control) & $\mathbf{- 0 . 2}$ & $\mathbf{- 0 . 4}$ & $\mathbf{- 0 . 6}$ & Mean \\
\cline { 2 - 7 } & DZ19-2 & $0.86 \mathrm{ab}$ & $0.72 \mathrm{~b}-\mathrm{e}$ & $0.55 \mathrm{e}-\mathrm{h}$ & $0.51 \mathrm{f}-\mathrm{h}$ & 0.66 \\
\cline { 2 - 7 } & Lucilla & $0.97 \mathrm{a}$ & $0.70 \mathrm{~b}-\mathrm{g}$ & $0.67 \mathrm{~b}-\mathrm{h}$ & $0.55 \mathrm{e}-\mathrm{h}$ & 0.72 \\
\cline { 2 - 7 } & EZ19-1 & $0.76 \mathrm{~b}-\mathrm{d}$ & $0.62 \mathrm{c}-\mathrm{h}$ & $0.57 \mathrm{~d}-\mathrm{h}$ & $0.52 \mathrm{f}-\mathrm{h}$ & 0.62 \\
\cline { 2 - 7 } & Wafia & $0.82 \mathrm{a}-\mathrm{c}$ & $0.73 \mathrm{~b}-\mathrm{e}$ & $0.48 \mathrm{~h}$ & $0.47 \mathrm{~h}$ & 0.62 \\
\cline { 2 - 7 } & Mean & $0.71 \mathrm{~b}-\mathrm{f}$ & $0.71 \mathrm{~b}-\mathrm{f}$ & $0.51 \mathrm{f}-\mathrm{h}$ & $0.50 \mathrm{gh}$ & 0.60 \\
\hline
\end{tabular}

Means within columns followed by different lowercase letters are significantly different

The average seed vigour decreased statistically with the increasing levels of drought stress. When the average seed vigour among genotypes was examined, the highest germination was observed in Envoy genotype, and the lowest was in 
DZ19-1, which was statistically similar to DZ19-2, Wafia, and Lucilla genotypes (Table 10). The size of seed is positively correlated with the seed vigor, and larger sized seeds have a tendency to produce more vigorous seedlings (Ries and Everson, 1973). It was pointed out that bolder seeds produced vigorous seedlings, taller plants with greater tillering, and higher dry matter as compared to smaller seeds under drought stress (Westoby et al., 1996).

Table 10. Response of PEG 6000 induced drought stress on the seed vigour (\%) of wheat genotypes

\begin{tabular}{|l|l|l|l|l|l|l|}
\hline \multirow{4}{*}{$\begin{array}{l}\text { Seed } \\
\text { vigour } \\
(\boldsymbol{\%})\end{array}$} & Genotypes & \multicolumn{5}{|c|}{ Levels of stress (MPa) } \\
\cline { 2 - 7 } & $\mathbf{0}$ (control) & $\mathbf{- 0 . 2}$ & $\mathbf{- 0 . 4}$ & $\mathbf{- 0 . 6}$ & Mean \\
\cline { 2 - 7 } & DZ19-2 & 75.00 & 83.33 & 83.33 & 58.33 & $75.00 \mathrm{~b}$ \\
\cline { 2 - 7 } & DZ19-1 & 91.67 & 85.00 & 75.00 & 73.33 & $81.25 \mathrm{~b}$ \\
\cline { 2 - 7 } & Envoy & 98.33 & 90.00 & 80.00 & 61.67 & $80.00 \mathrm{~b}$ \\
\cline { 2 - 7 } & Wafia & 98.33 & 83.33 & 85.00 & 80.00 & $89.17 \mathrm{a}$ \\
\cline { 2 - 7 } & Mean & $90.33 \mathrm{a}$ & $88.00 \mathrm{a}$ & $80.33 \mathrm{~b}$ & $66.23 \mathrm{c}$ & \\
\hline
\end{tabular}

Means within columns followed by different lowercase letters are significantly different

\section{Proline}

Proline is one of the most important metabolites which acts as cytosolute different types of environmental stresses like drought, high temperature, nutrient deficiency, exposure of heavy metals, and high acidity induced to accumulate proline for adaptation of plants (Oncel et al., 2000; Chen and Murata, 2002; Yasar et al., 2006; Wang, 2012).

The increased proline content under drought helps for osmotic adjustment. Genotypes, PEG-6000 induced stresses, and their interaction were statistically significant at $1 \%$ level (Tables 1 \& 11). At increased PEG concentrations, the amount of proline increased compared to the control condition. However, the DZ19-1genotype accumulated the highest amount of proline $(2.19 \mathrm{micromol} / \mathrm{g})$ under control condition, and maintained the similar trends at all stress levels, indicating it as a drought tolerant genotype. The genotype Envoy produced the lowest proline content under stress conditions (Table 11). Plants under drought produce compatible solutes to maintain cell turgor, which results in reduced osmotic stress in plants (Silva et al., 2010). One of the important compatible solutes is proline, which acts as a protectant to defend cell membrane and also as an ROS scavenger that could provide energy for growth and survivability under stress condition (Sankar et al., 2007; Rezayian et al.,2018).

\section{Chlorophyll a}

The chlorophyll a $(\mathrm{Chl} a)$ content was significantly influenced by the genotypes and drought stress, and their interaction between drought stress and genotype. The values of $C h l a$ decreased with the increase of drought stresses, and the lowest values were recorded at the severe drought stress in all the genotypes. Nevertheless, the genotypes DZ19-2 and DZ19-1 showed the highest 
amount of Chl a (0.90 and $0.83 \mathrm{mg} / \mathrm{g}$, respectively) under control conditions well as under severe drought condition (Table 12). Chl content is known as an index of photosynthates for the evaluation of source (Zobayed et al., 2007), therefore decrease of Chl a can be considered as a non-stoma limiting factor in the drought stress conditions (Khayatnezhad and Gholamin, 2012). Stress can cause a change in chlorophyll content of plant leaves, and thus a change of photosynthetic function (Qian et al., 2003). Manivannan et al. (2007) concluded that Chl a, Chl $b$, and the total chlorophyll contents in sunflower varieties are considerable reduced due to drought stress.

Table 11. Response of PEG 6000-induced drought stress on the proline content of wheat genotypes

\begin{tabular}{|l|l|l|l|l|l|l|}
\hline \multirow{5}{*}{$\begin{array}{l}\text { Proline } \\
\text { (micromol/genpes }\end{array}$} & \multicolumn{5}{|c|}{ Levels of stress (MPa) } \\
\cline { 2 - 7 } & & $\mathbf{0}$ (control) & $\mathbf{- 0 . 2}$ & $\mathbf{- 0 . 4}$ & $\mathbf{- 0 . 6}$ & Mean \\
\cline { 2 - 7 } & DZ19-2 & $0.81 \mathrm{e}$ & $1.34 \mathrm{de}$ & $2.40 \mathrm{ab}$ & $2.31 \mathrm{ab}$ & $1.72 \mathrm{~b}$ \\
\cline { 2 - 7 } & Lucilla & $1.36 \mathrm{de}$ & $1.20 \mathrm{de}$ & $1.21 \mathrm{de}$ & $1.60 \mathrm{~cd}$ & $1.35 \mathrm{~cd}$ \\
\cline { 2 - 7 } & DZ19-1 & $2.19 \mathrm{bc}$ & $2.67 \mathrm{ab}$ & $2.95 \mathrm{a}$ & $2.44 \mathrm{ab}$ & $2.56 \mathrm{a}$ \\
\cline { 2 - 7 } & Envoy & $1.00 \mathrm{de}$ & $0.95 \mathrm{de}$ & $1.27 \mathrm{de}$ & $1.16 \mathrm{de}$ & $1.10 \mathrm{~d}$ \\
\cline { 2 - 7 } & Wafia & $1.01 \mathrm{de}$ & $1.26 \mathrm{de}$ & $0.96 \mathrm{de}$ & $2.72 \mathrm{ab}$ & $1.49 \mathrm{bc}$ \\
\cline { 2 - 7 } & Mean & $1.27 \mathrm{c}$ & $1.49 \mathrm{bc}$ & $1.76 \mathrm{ab}$ & $2.05 \mathrm{a}$ & \\
\hline
\end{tabular}

Means within columns followed by different lowercase letters are significantly different

\section{Chlorophyll-b}

Drought stress had remarkable differential influence on the chlorophyll $b$ ( $C h l b$ ) content in the shoots. The $C h l b$ was also significantly (1\%) influenced by the interaction between PEG-6000 and genotypes (Table 1 \& 13). DZ19-2 genotype accumulated the highest amount of $C h l b$ in control condition $(0.47$ $\mathrm{mg} / \mathrm{g})$, and the lowest in drought stress of $-0.6 \mathrm{MPa}(0.21 \mathrm{mg} / \mathrm{g})$. However, the DZ19-1 genotype showed the minimum resistance as against the drought stress of both -0.4 and -0.6 MPa. The minor changes in chlorophyll content and the stability of chlorophyll $\mathrm{a} / \mathrm{b}$ ratio allow to conclude that the pigment apparatus is comparatively resistant to drought in wheat cultivars (Nikolaeva et al.,2010). Decreased or unchanged chlorophyll level during drought stress has been reported in many species, depending on the duration and severity of drought stress (Hu et al., 2007; Xu et al., 2020).

\section{Total chylorophyll}

Chlorophyll fluorescent is used as a stress tolerant index to study the effects of different kinds of stresses (Zobayed et al., 2007).Total chlorophyll content was remarkably influenced by the wheat genotypes; PEG-6000 induced drought stress, and their interaction (Table $1 \&$ 14). In this study, the DZ19-2 genotype had the highest amount of chlorophyll under control. Although, the genotype Envoy protect its chlorophyll content as against the increased drought stress levels (like DZ19-2), and it was also statistically similar to DZ19-2 and 
Envoy. The decrease in chlorophyll content under drought stress has been considered a typical symptom of oxidative stress, and Pigment photo-oxidation and chlorophyll degradation are responsible for diminishing the chlorophyll content in drought stress, and is considered as a typical symptom of oxidative stress (Sharif and Mohammadkhani, 2016).A similar dependence of chlorophyll content in dehydrated leaves was previously observed in barley seedlings by Pshibytko et al. (2004). The chlorophyll content in the non-stress treatment is higher than that of the drought stress treatments (Xu et al., 2020).

Table 12. Response of PEG 6000 induced drought stress on the chlorophyll a of wheat genotypes

\begin{tabular}{|l|l|l|l|l|l|l|}
\hline \multirow{4}{*}{ Genotypes } & \multicolumn{5}{|c|}{ Levels of stress (MPa) } \\
\cline { 2 - 7 } & & $\mathbf{0}$ (control) & $\mathbf{- 0 . 2}$ & $\mathbf{- 0 . 4}$ & $\mathbf{- 0 . 6}$ & Mean \\
\cline { 2 - 7 } & DZ19-2 & $0.90 \mathrm{a}$ & $0.59 \mathrm{~b}-\mathrm{d}$ & $0.52 \mathrm{~d}$ & $0.51 \mathrm{~d}-\mathrm{f}$ & $0.63 \mathrm{a}$ \\
\hline \multirow{5}{*}{$\begin{array}{l}\text { Chlorophyll a } \\
(\mathbf{m g})\end{array}$} & Lucilla & $0.55 \mathrm{~cd}$ & $0.41 \mathrm{~g}$ & $0.39 \mathrm{~g}$ & $0.25 \mathrm{~h}$ & $0.40 \mathrm{~d}$ \\
\cline { 2 - 7 } & DZ19-1 & $0.83 \mathrm{a}$ & $0.63 \mathrm{bc}$ & $0.30 \mathrm{~h}$ & $0.42 \mathrm{fg}$ & $0.55 \mathrm{~b}$ \\
\cline { 2 - 7 } & Envoy & $0.68 \mathrm{~b}$ & $0.51 \mathrm{de}$ & $0.67 \mathrm{~b}$ & $0.43 \mathrm{e}-\mathrm{g}$ & $0.57 \mathrm{~b}$ \\
\cline { 2 - 7 } & Wafia & $0.65 \mathrm{~b}$ & $0.41 \mathrm{~g}$ & $0.42 \mathrm{fg}$ & $0.40 \mathrm{~g}$ & $0.47 \mathrm{c}$ \\
\cline { 2 - 7 } & Mean & $0.72 \mathrm{a}$ & $0.51 \mathrm{~b}$ & $0.46 \mathrm{c}$ & $0.40 \mathrm{~d}$ & 0.52 \\
\hline
\end{tabular}

Means within columns followed by different lowercase letters are significantly different

Table 13. Response of PEG 6000 induced drought stress on the chlorophyll b of wheat genotypes

\begin{tabular}{|l|l|l|l|l|l|l|}
\hline \multirow{4}{*}{$\begin{array}{c}\text { Genotypes } \\
\text { Chlorophyll } \\
(\mathbf{m g} / \mathbf{g})\end{array}$} & \multicolumn{5}{|c|}{ Levels of stress (MPa) } \\
\cline { 2 - 7 } & $\mathbf{0}$ (control) & $\mathbf{- 0 . 2}$ & $\mathbf{- 0 . 4}$ & $\mathbf{- 0 . 6}$ & Mean \\
\cline { 2 - 7 } & DZ19-2 & $0.47 \mathrm{a}$ & $0.28 \mathrm{c}-\mathrm{e}$ & $0.22 \mathrm{e}-1$ & $0.21 \mathrm{e}-1$ & $0.29 \mathrm{a}$ \\
\hline & Lucilla & $0.24 \mathrm{~d}-\mathrm{h}$ & $0.19 \mathrm{~g}-1$ & $0.20 \mathrm{f}-1$ & $0.20 \mathrm{~g}-1$ & $0.21 \mathrm{~b}$ \\
\cline { 2 - 7 } & DZ19-1 & $0.33 \mathrm{bc}$ & $0.25 \mathrm{~d}-\mathrm{g}$ & 0.161 & 0.171 & $0.23 \mathrm{~b}$ \\
\cline { 2 - 7 } & Envoy & $0.36 \mathrm{~b}$ & $0.30 \mathrm{~b}-\mathrm{d}$ & $0.27 \mathrm{c}-\mathrm{f}$ & $0.17 \mathrm{1}$ & $0.27 \mathrm{a}$ \\
\cline { 2 - 7 } & Wafia & $0.21 \mathrm{e}-1$ & $0.17 \mathrm{~h} 1$ & $0.20 \mathrm{e}-1$ & $0.19 \mathrm{~g}-1$ & $0.20 \mathrm{~b}$ \\
\cline { 2 - 7 } & Mean & $0.32 \mathrm{a}$ & $0.24 \mathrm{a}$ & $0.21 \mathrm{bc}$ & $0.19 \mathrm{c}$ & \\
\hline
\end{tabular}

Means within columns followed by different lowercase letters are significantly different

\section{Carotenoid}

Genotypes, PEG-6000 induced drought stresses, and their interaction were found significant at $1 \%$ level on the carotenoid content. Differential responses among the genotypes regarding carotenoid content were recorded under control and PEG induced drought stress conditions. The carotenoid content gradually decreased with increasing drought stress from 0 (Control) to -0.6 MPa. However, at the highest level of drought stress (-0.6 MPa), the genotype DZ19-2 recorded the highest carotenoid content $(0.17 \mathrm{mg} / \mathrm{g})$, which was statistically identical with Envoy, DZ19-1 and Wafia genotypes. In previous reports, Shmat'ko and Shvedova (1977) revealed that drought resistant wheat varieties exhibited a minor or no change in the pigment content compared to drought susceptible varieties. 
The result differs from those of Wang (2003), who reported that the carotenoid content in leaves of winter wheat increased under drought stress.

Table 14. Response of PEG 6000 induced drought stress on the total chlorophyll of wheat genotypes

\begin{tabular}{|l|l|l|l|l|l|l|}
\hline \multirow{4}{*}{$\begin{array}{c}\text { Total } \\
\text { chlorophIl(mg/g) }\end{array}$} & Genotypes & \multicolumn{5}{|c|}{ Levels of stress (MPa) } \\
\cline { 2 - 7 } & & $\mathbf{0}$ (control) & $\mathbf{- 0 . 2}$ & $\mathbf{- 0 . 4}$ & $\mathbf{- 0 . 6}$ & Mean \\
\cline { 2 - 7 } & DZ19-2 & $1.72 \mathrm{a}$ & $1.13 \mathrm{de}$ & $0.93 \mathrm{f}$ & $0.89 \mathrm{fg}$ & $1.17 \mathrm{a}$ \\
\cline { 2 - 7 } & Lucilla & $1.01 \mathrm{ef}$ & $0.74 \mathrm{gh}$ & $0.74 \mathrm{~h}$ & $0.54 \mathrm{j}$ & $0.76 \mathrm{~d}$ \\
\cline { 2 - 7 } & DZ19-1 & $1.50 \mathrm{~b}$ & $1.13 \mathrm{de}$ & $0.58 \mathrm{ij}$ & $0.73 \mathrm{~h}$ & $0.99 \mathrm{~b}$ \\
\cline { 2 - 7 } & Envoy & $1.30 \mathrm{c}$ & $1.38 \mathrm{bc}$ & $1.23 \mathrm{~cd}$ & $0.75 \mathrm{gh}$ & $1.16 \mathrm{a}$ \\
\cline { 2 - 7 } & Wafia & $1.10 \mathrm{de}$ & $0.73 \mathrm{hi}$ & $0.78 \mathrm{gh}$ & $0.73 \mathrm{~h}$ & $0.83 \mathrm{c}$ \\
\cline { 2 - 7 } & Mean & $1.33 \mathrm{a}$ & $1.02 \mathrm{~b}$ & $0.85 \mathrm{c}$ & $0.73 \mathrm{~d}$ & 0.98 \\
\hline
\end{tabular}

Means within columns followed by different lowercase letters are significantly different

Table 15. Response of PEG 6000 induced drought stress on the carotenoid content of wheat genotypes

\begin{tabular}{|l|l|l|l|l|l|l|}
\hline \multirow{4}{*}{$\begin{array}{c}\text { Carotenoid } \\
(\mathbf{m g} / \mathbf{g})\end{array}$} & Genotypes & \multicolumn{5}{|c|}{ Levels of stress (MPa) } \\
\cline { 2 - 7 } & & $\mathbf{0}$ (control) & $\mathbf{- 0 . 2}$ & $\mathbf{- 0 . 4}$ & $\mathbf{- 0 . 6}$ & Mean \\
\cline { 2 - 7 } & DZ19-2 & $0.36 \mathrm{a}$ & $0.26 \mathrm{~cd}$ & $0.19 \mathrm{fg}$ & $0.17 \mathrm{f}-\mathrm{h}$ & $0.25 \mathrm{a}$ \\
\cline { 2 - 7 } & Lucilla & $0.21 \mathrm{ef}$ & $0.15 \mathrm{hi}$ & $0.14 \mathrm{hi}$ & $0.10 \mathrm{j}$ & $0.15 \mathrm{c}$ \\
\cline { 2 - 7 } & DZ19-1 & $0.33 \mathrm{ab}$ & $0.25 \mathrm{~cd}$ & $0.11 \mathrm{ij}$ & $0.14 \mathrm{hi}$ & $0.21 \mathrm{~b}$ \\
\cline { 2 - 7 } & Envoy & $0.25 \mathrm{~cd}$ & $0.16 \mathrm{gh}$ & $0.29 \mathrm{bc}$ & $0.15 \mathrm{~g}-\mathrm{i}$ & $0.21 \mathrm{~b}$ \\
\cline { 2 - 7 } & Wafia & $0.24 \mathrm{de}$ & $0.14 \mathrm{hi}$ & $0.16 \mathrm{gh}$ & $0.14 \mathrm{hi}$ & $0.17 \mathrm{c}$ \\
\cline { 2 - 7 } & Mean & $0.28 \mathrm{a}$ & $0.19 \mathrm{~b}$ & $0.18 \mathrm{~b}$ & $0.14 \mathrm{c}$ & \\
\hline
\end{tabular}

Means within columns followed by different lowercase letters are significantly different

\section{CONCLUSIONS}

Water stress significantly reduced the germination, seedling growth and physiological properties in all wheat genotypes, and the genotype DZ19-1 showed the best performance against the drought stress. The proline level was increased due to drought stress, and the highest proline levels were observed in the DZ19-1 genotype. Among the tested genotypes, DZ19-1 can be treated as a drought tolerant genotype due to performing most excellent growth during seedling stage under drought conditions.

\section{REFERENCES}

Abbasi, A., Shekari, F., \& Mustafavi S.H. (2015). Effect of paclobutrazol and salicylic acid on antioxidants enzyme activity in drought stress in wheat. IDESIA (Arica), $33,5-13$.

Alom, R., Hasan, M. A., Islam, M.R., \& Wang, Q. F. (2016). Germination characters and early seedling growth of wheat (Triticum aestivum L.) genotypes under salt stress conditions. J Crop Sci Biotechnol 19, 383-392. 
Agarwal, B. (1986). Cold Hearths and Barren Slopes: The Woodfuel Crisis in the Third World, Allied Publishers, New Delhi.

Aslam, M., Zamir, M.S.I., Afzal, I., Yaseen, M., Mubeen, M. \& Shoaib, A. (2013). Drought stress, its effect on maize production and development of drought tolerance through potassium application. Journal Cercetări Agronomiceîn Moldova (Agronomical Research in Moldavia), Iaşi - Romania. Vol. XLVI, No. 2 (154), 99-114.

Barutcular, C., Yıldırım, M., Koç, M., Akıncı, C., Tanrıkulu, A., EL Sabagh, et al. (2016). Quality traits performance of bread wheat genotypes under drought and heat stress conditions. Fresenius Environmental Bulletin, 25(12a), 6159-6165.

Barutçular, C., EL Sabagh, A., Koç, M., \& Ratnasekera, D. (2017). Relationships between grain yield and physiological traits of durum wheat varieties under drought and high temperature stress in Mediterranean conditions. Fresenius Environmental Bulletin, 26(4), 4282-4291

Bateman, A., Lewandrowski, W., Stevens, J., \&Muñoz-Rojas, M. (2016). The limitations ofseedling growth and drought tolerance to novel soil substrates in arid systems:implications for restoration success. Geophys Res Abstr 18, 1-2.

Bates, L. S., Waldren, R. P., \& Teare, I. D. (1973). Rapid determination of free proline for water-stress studies. Plant and Soil, 39, 205-207.

Chachar, M. H., Chachar, N. A., Chachar, S. D., Chachar, Q. I., Mujtaba, S. M., Yousafzai, A. (2014). Invitro screening technique for drought tolerance of wheat (Triticum aestivium L.) genotypes at early seedling stage. International Journal of Agricultural Technology, 10, 1439-1450.

Chen, T. H. H. \& Murata, N. (2002). Enhancement of tolerance of abiotic stress by metabolic engineering of betaines and other compatible solutes. Curr. Opin. Plant Biol., 5, 250-257.

Duan, H., Zhu, Y., Li, J., Ding, W., Wang, H., Jiang, L., \& Zhou, Y. (2017). Effects of drought stress on growth and development of wheat seedlings. International journal of agriculture and biology, 19(5), 1119-1124.

Duncan, B. D., (1955). Multiple ranges and multiple F. test. Biometrics, 11, 1-42.

Dončić, D., Popović, V., Lakić, Ž., Popović, D., \& Petković, Z. (2019). Economic analysis of wheat production and applied marketing management. Agriculture and Forestry, 65 (4), 91-100.

EL Sabagh, A., Hossain, A., Islam, M. S., Barutcular, C., Ratnasekera, D., Gormus, O., et al. (2020). Drought and Heat Stress in Cotton (Gossypium hirsutum L.): Consequences and Their Possible Mitigation Strategies. In: Hasanuzzaman M. (eds) Agronomic Crops. Springer, Singapore.

EL Sabagh, A., Hossain, A., Barutcular, C., Islam, M. S., Awan, S., Galal, A., \& Fahad, S. (2019). Wheat (Triticum aestivum L.) production under drought and heat stressadverse effects, mechanisms, and mitigation. Applied Ecology and Environmental Research, 17(4), 8307-8332.

Gomez, K. A., \& Gomez, A. A., (1984). Duncan's multiple range test. Statistical procedures for agricultural research. A Wiley Int. Sci. Pub. John Wiley and Sons, New York, USA. pp. 139-240.

Guo, X., Xin, Z., Yang, T., Ma, X., Zhang, Y., Wang, Z., Ren, Y., \& Lin, T. (2020). Metabolomics response for drought stress tolerance in Chinese wheat genotypes (Triticum aestivum). Plants, 9, 520; doi:10.3390/plants9040520. 
Guoxiong, C., Krugman, T., Fahima, T., Korol, A. B., \& Nevo, E. (2002). Comparative study on morphological and physiological traits related to drought resistance between xeric and mesic Hordeum spontaneum lines in Isreal. Barley Genet. Newslett. 32, 22-33.

Higazy, M. A., Shehata M. M., \& Allam, A. I. (1995). Free proline relation to salinity tolerance of three sugar beet varieties. Egypt. J. Agric. Res., 73 (1), 175-191.

Hu, S.P. Wang, Z.G. Zhang, L. Liu, G. Luo, L., \& Liao, H. (2007). Correlation analysis and gene identification for chlorophyll content and photosynthetic rate in rice leaves under drought stress. Chin. J. Biochem. Mol. Biol.2007, 23, 926-932.

Islam, M. M, Kayesh, E., Zaman, E., Urmi, T. A., \& Haque, M. M. (2018). Evaluation of rice (Oryza sativa L.) genotypes for drought tolerance at germination and early seedling stage. The Agriculturists. 16(1), 44-54.

Jajarmi, V. 2009. Effect of water stress on germination indices in seven wheat cultivars. World Academy of Science, Eng. Technol., 49:105-106

Janiak, A., Kwasniewski M., \& Szarejko, I. (2015). Gene expression regulation in roots under drought. J. Exp. Bot., 67, 142-147.

Jatoi, S. Latif, A., Arif, M. M., Ahson, M., Khan, M., \& Siddiqui, S. U. (2014). Comparative assessment of wheat landraces against polyethylene glycol simulated drought stress. Sci. Tech. and Dev. 33, 1-6.

Kaydan, D., \& Yagmur, M. (2008). Germination, seedling growth and relative water content of shoot in different seed sizes of triticale under osmotic stress of water and $\mathrm{NaCl}$. African Journal of Biotechnology ,7, 2862-2868.

Khayatnezhad, M., \& Gholamin, R. (2012). The effect of drought stress on leaf chlorophyll content and stress resistance in maize cultivars (Zea mays). African Journal of Microbiology Research, 6(12), 2844-2848.

Kizilgeci, F., Tazebay, N., Namli, M., Albayrak, O., \& Yildirim, M. (2017). The drought effect on seed germination and seedling growth in bread wheat (Triticum aestivum L.). Int J Agric Environ Food Sci., 1, 33-37.

Kizilgeci, F, Ebrahim Pour Mokhtari, N., \& Hossain, A. (2020). Growth and physiological traits of five bread wheat (Triticum aestivum L.) genotypes are influenced by different levels of salinity and drought stress. Fresenius Environmental Bulletin, 29(9A), 8592-8599.

Malik, Al., Colmer, T. D., Lambers, H., Setter, T. L., \& Schortmeyer, M. (2002). Shortterm waterlogging has long-term effects on the growth and physiology of wheat. New Phytol., 153, 225-236.

Manivannan, P., Jaleel, C. A., Kishorekumar, A., Sankar, B., Somasundaram, R., Sridharan, R., \& Panneerselvam, R. (2007). Changes in antioxidant metabolism of Vigna unguiculata L. Walp. by propiconazole under water deficit stress. Colloids Surf B: Biointerf., 57, 69-74.

Monsur, M. B., Ivy, N. A., Haque, M. M., Hasanuzzaman, M., \& EL Sabagh, A. (2020). Oxidative Stress Tolerance Mechanism in Rice under Salinity. PhytonInternational Journal of Experimental Botany, 89(3), 497-517.

Mickky, B. M., \& Aldesuquy, H. S. (2017). Impact of osmotic stress on seedling growth observations, membrane characteristics and antioxidant defense system of different wheat genotypes. Egypt J Basic Appl Sci 4, 47-54. 
Molla, M. S. H., Nakasathien, S., Ali, M. A., Khan, A.S.M.M.R., Alam, M.R., Hossain, A., Farooq, M. \& El Sabagh, A., (2019). Influence of nitrogen application on dry biomass allocation and translocation in two maize varieties under short preanthesis and prolonged bracketing flowering periods of drought. Archives of Agronomy and Soil Science, 65(7), 928-944.

Mubeen, M., Ahmad, A., Hammad, H. M., Awais, M., Farid, H. U., Saleem, M., et al. (2020). Evaluating the climate change impact on water use efficiency of cottonwheat in semi-arid conditions using DSSAT model. Journal of Water and Climate Change, 11(4), 1661-1675.

Mwadzingeni, L., Shimelis, H., Dube, E., Laing, M.D., \& Tsilo, T.J. (2016). Breeding wheat for drought tolerance: progress and technologies. J. Integr. Agric., 15, 935-943.

Mwale, S., Hamusimbi, C., \& Mwansa, K. (2003). Germination, emergence and growth of sunflower (Helianthus annuus L.) in response to osmotic seed priming. Seed Sci. Technol., 31, 199-206.

Nikolaeva MK, Maevskaya SN, Shugaev AG, \& Bukhov NG (2010). Effect of drought on chlorophyll content and antioxidant enzyme activities in leaves of three wheat cultivars varying in productivity. Russ J Plant Physiol 57: 87-95.

Oncel, I., Kelas, Y., \& Ustun, A. S. (2000). Interactive effects of temperature and heavy metal stress on the growth and some biochemical compounds in wheat seedling. Environ. Pollut., 107, 315-320.

Öztürk, A., Taşkesenligil, B., Haliloğlu, K., Aydin, M., \& Çağlar, Ö. (2016). Evaluation of bread wheat genotypes for early drought resistance via germinationunder osmotic stress, cell membrane damage, and paraquat tolerance. Turk $\mathbf{J}$ Agric for 40, 146-159.

Panfilova, A., \& Mohylnytska, A. (2019). The impact of nutrition optimization on crop yield of winter wheat varieties (Triticum aestivum L.) and modeling of regularities of its dependence on structure indicators. Agriculture and Forestry, 65(3), 157 171.

Partheeban, C., Chandrasekhar, C. N. Jeyakumar, P., Ravikesavan, R. \& Gnanam, R. (2017). Effect of PEG induced drought stress on seed germination and seedling characters of maize (Zea mays L.) genotypes. Int. J. Curr. Microbiol. App. Sci. 6(5), 1095-1104.

Patade, V. Y., Maya, K., Zakwan, A. (2011). Seed priming mediated germinationimprovement and tolerance to subsequent exposure to cold and salt stressin capsicum. Res J Seed Sci, 4, 125-36.

Popović, V., Ljubičić, N., Kostić, M., Radulović, M., Blagojević, D., Ugrenović, V., Popović, D., \& Ivosević, B. (2020). Genotype x Environment interaction for wheat yield traits suitable for selection in different seed priming conditions. Plants. 9(12), 1804.

Pshibytko, N. L., Kalitukho, L. N., Zhavoronkova, N. B., \& Kabashnikova, L. F., (2004). The pool of chlorophyllous pigments in barley seedlings of different ages under heat shock and water deficit, Russ. J. Plant Physiol., 51, 15-20.

Qian, X. Q. Shen, Q. R. Xu, Y.;Wang, J. \& Shen, H. (2003). Water use efficiency and rice yield under different water managements. Chin. J. Appl. Ecol. 14, 399.

Rana, M. S., Hasan, M. A., Bahadur, M. M., \& Islam, M. R. (2017). Effect of polyethylene glycol induced water stress on germination and seedling growth of wheat (Triticum aestivum L.). The Agriculturists, a Scientific Journal of Krishi Foundation. 15(1), 81-91. 
Rezayian, M., Niknam, V., \& Ebrahimzadeh, H. (2018). Effects of drought stress on the seedling growth, development, and metabolic activity in different cultivars of canola. Soil Science and Plant Nutrition, 64(3), 360-369.

Ries, S. K., \&Everson, E. H. (1973). Protein content and seed size relationships with seedling vigor of wheat cultivars. Agron. J. 65, 884- 886.

Salih, S., \& Tuncturk, R. (2020). Low doses of gibberellic acid can enhance germination of wheat seed under drought stress. Adv Crop Sci Tech., 8(1), 432.

Sankar, B., Jaleel, C., Manivannan, P., Kishorekuma, A., Somasundaram, R., \& Panneerselvan, R. (2007) Drought induced biochemical modification and proline metabolism in Abelmoschus esculentus (L.) Moench. Acta Bot. Croat., 66, 43-56.

Sayar, R., Bchini, H., Mosbahi, M., \&Khemira, H. (2010). Response of durum wheat (Triticum durum Desf.) growth to salt and drought stresses. Czech J. Genet. Plant Breed., 46, 54-63.

Sharif, P., \& Mohammadkhani, N. (2016). Effects of drought stress on photosynthesis factors in wheat genotypes during anthesis. Cereal Research Communication, 44(2), 229-239.

Shmat'ko, I. G. \& Shvedova, O. E. (1977). Vodnyi rezhim i zasukhoustoichivost' pshenitsy (Water Regime and Wheat Drought Tolerance), Kiev: Naukova Dumka.

Silva, E. N., Ferreira-Silva, S. L., Viégas, R. A., \& Silveira, J. A. G. (2010). The role of organic and inorganic solutes in the osmotic adjustment of drought stressed Jatrophacurcas plants. Environ. Exp. Bot., 69, 279-285

Španić, V., Ižaković, M., \& Marček, T. (2017). Wheat germination and seedlings under PEG-induced conditons. Agronomski glasnik: Glasilo Hrvatskog agronomskog društva, 79(3), 99-109.

Turner, N.C. (1997). Further progress in crop water relations. Adv. Agron., 58, 293-338.

Vardar, Y., Çifci, E.A., \& Yağdi, K. (2014). Salinity Effects on Germination Stage of Bread and Durum Wheat Cultivars. Yyu. J. Agr. Sci., 24(2): 127- 139.

Wang, W., Vinocur, B., \& Altman, A. (2003). Plant responses to drought, salinity and extreme temperatures: towards genetic engineering for stress tolerance. Planta, 218(1), 1-14.

Wang, H. (2012). Effects of salt stress on ion balance and nitrogen metabolism of old and young leaves in rice (Oryza sativa L.). BMC Plant Biol., 12, 194.

Westoby, M., Leishman, M., \& Lord, J. (1996). Comparative ecology of seed size and dispersal. Philos. Trans. Royal Soc. London B. Biol. Sci. 351, 1309-1318.

Wikipedia (2020). Polyethylene glycol. https://en.wikipedia.org/wiki/Polyethylene_glycol (page accessed on June 01, 2020).

Xu, Q, Ma, X., Lv, T., Bai, M., Wang, Z. \& Niu, J. (2020). Effects ofWater Stress on Fluorescence Parameters and Photosynthetic Characteristics of Drip Irrigation in Rice. Water, 12, 289.

Yasar, F., Uzal, O., Tufenkci, S., Yildiz, K., Pasa, O. (2006). Ion accumulation in different organs of green bean genotypes grown under salt stress. Plant Soil Environ., 52, 476. 
Yassin, M., El Sabagh, A., Mekawy, A.M.M., Islam, M.S., Hossain, A., Barutcular, C., et al. (2019). Comparative performance of two bread wheat (Triticum aestivum L.) Genotypes Under Salinity Stress. Applied Ecology and Environmental Research, 17(2), 5029-5041.

Zaman, G., Murtaza, B., Imran, M., Shahid, M., Shah, G. M., Amjad, M., et al. (2020). Utilization of compost from bio-municipal solid waste improves salinesodic soils and crop productivity in rice-wheat. Compost Science \& Utilization, 28(1), 16-27

Zobayed, S. M. A., Afreen, F., \& Kozai, T. (2007). Phytochemical and physiological changes in the leaves of St. John's wort plants under a water stress condition. Environ. Exper. Bot., 59, 109-116. 